\title{
Retraction Note to: Osteoblastic differentiation of stem cells induced by graphene oxide-hydroxyapatite-alginate hydrogel composites and construction of tissue-engineered bone
}

\author{
Xuanze $\mathrm{Li}^{1,2,3,4} \cdot$ Jiao Chen ${ }^{2,4} \cdot$ Zhe $\mathrm{Xu}^{1,4} \cdot$ Qiang Zou ${ }^{1,2,4} \cdot$ Long Yang ${ }^{1,2,4} \cdot$ Minxian $\mathrm{Ma}^{2,3,4} \cdot$ Liping Shu ${ }^{2,3,4}$. \\ Zhixu $\mathrm{He}^{2} \cdot$ Chuan $\mathrm{Ye} \mathbb{1}^{1,2,3,4,5}$
}

Published online: 11 June 2021

(c) The Author(s) 2021

Retraction to: Journal of Materials Science: Materials in Medicine (2020) 31:125

https://doi.org/10.1007/s10856-020-06467-6

This article has been retracted at the request of the authors due to the multiple errors in Fig. 13. As some in vivo data are flawed, the conclusions of the article are no longer viable. The authors sincerely apologize to readers and the journal for any inconvenience caused. The authors are repeating their study and will submit a corrected manuscript for peer review. All authors agree to this retraction.
Open Access This article is licensed under a Creative Commons Attribution 4.0 International License, which permits use, sharing, adaptation, distribution and reproduction in any medium or format, as long as you give appropriate credit to the original author(s) and the source, provide a link to the Creative Commons license, and indicate if changes were made. The images or other third party material in this article are included in the article's Creative Commons license, unless indicated otherwise in a credit line to the material. If material is not included in the article's Creative Commons license and your intended use is not permitted by statutory regulation or exceeds the permitted use, you will need to obtain permission directly from the copyright holder. To view a copy of this license, visit http://creativecommons. org/licenses/by/4.0/.
The original article can be found online at https://doi.org/10.1007/ s10856-020-06467-6.

Chuan Ye

yechuanchina@hotmail.com

1 Department of Orthopaedics, The Affiliated Hospital of Guizhou Medical University, 550004 Guiyang, China

2 Key Laboratory of Adult Stem Cell Transformation Research, Chinese Academy of Medical Sciences, 550004 Guiyang, China

3 National-Local Joint Engineering Laboratory of Cell Engineering and Biomedicine, 550004 Guiyang, China

4 Center for Tissue Engineering and Stem Cell Research, Guizhou Medical University, 550004 Guiyang, China

5 China Orthopaedic Regenerative Medicine Group (CORMed), 310000 Hangzhou, China 